\title{
Investment, Savings, Interest Rate and Bank Credit to the Private
}

\section{Sector Nexus in Pakistan}

\author{
Rahila Munir, Rehmat Ullah Awan \& Zakir Hussain \\ Department of Economics, University of Sargodha, Pakistan
}

\begin{abstract}
The present study examines long run and short run association among Investment, Savings, Real Interest rate on Bank deposits and Bank Credit to the private sector, accompanied with the impact of financial liberalization on key macro economic variables in Pakistan for the period 1973 to 2007. ARDL Bounds Testing Approach has been applied for co-integration of annual time series data. To test the order of integration of the variables, DF-GLS and Ng-Perron Tests have been employed. The results show that Private Investment is positively affected by Savings, Real interest rate on bank deposits, Bank credit to private sector and Public investment in the long run in a developing country like Pakistan, supporting Complementarity Hypothesis of Mckinnon-Shaw (1973).
\end{abstract}

Keywords: ARDL Co-integration, Unit root, Error correction, Investment, Savings, Interest rate, Bank credit

\section{Introduction}

The central point of the McKinnon-Shaw (1973) hypothesis is that, an increase in the real interest rate may induce the savers to save more, which enables more investment. This may lead to complementarity between the accumulation of financial assets and physical capital accumulation.

The financial sector liberalization in developing countries focused on the measures that were intended to make the central bank more sovereign and independent, alleviate "financial repression" by freeing interest rates and allowing financial innovations, and reduce directed credit. This also allows more freedom in terms of external flows of capital in different forms. The financial repression leads to unproductive allocation of capital, low rate of returns to savers, high costs of financial intermediation and inhibits growth of an economy (Roubini and Sala-i-Martin, 1992).

The financial liberalisation increased the investment and raised interest rates. The low productivity of different sectors of the economy suggested that it was more profitable to reinvest in bank deposits, thus reducing investment in the low productivity sector. This increases the supply of credit for more productive sectors of the economy, raising quality of investment which promotes growth.

There exists a linkage between investment and savings and that the interest rate is the channel for equalization of both under the financial liberalization proposition (Correa and Rao, 2004). Athukorala (1998) supported the complementarity hypothesis of McKinnon and Shaw (1973) that high rate of interest stimulated investment through self financed savings in India. The policy of deregulation of the interest rate promotes the savings and investment and attains the efficient allocation of financial resources (Shrestha and Chowdhury, 2007). The growth of any economy depends on capital accumulation, and this requires investment with matching savings (Thirlwall, 2004).

Financial and other liberalization policies were under taken by many developing countries including Pakistan to achieve and promote higher level of growth. The costs of restrictive policies were huge and reflected in the form of low financial savings, investment and economic growth (Khan and Qayyum, 2006).

Owing to high inflation and inflationary outlook, the current levels of real interest rates have turned negative. Thus controlling of inflation was essential to curtail excessive domestic credit growth and encourage savings. Banks raised the interest rates on incremental deposits which reached 8.7 percent on average in 2008. Domestic resource mobilization was now critical to facilitate the investment demand to enhance the productive capacity of the economy which helped to reduce aggregate demand-supply gap (Zaidi, 2008).

Previous studies of Pakistan mostly focused on the financial development and analyzed its effect on economic growth. In this study, the intent is to analyze the effect of Private Savings, Real interest rate on bank deposits, Bank credit to the private sector and Public sector investment and financial liberalization policy on Private investment behavior in Pakistan. The rest of study is organized as follows. Section 2 gives the data, model and 
methodological framework. Empirical results are provided in section 3 and conclusion with recommendations is drawn in section 4.

\section{Data, Model and Methodological Framework}

Annual time series data (1973-2007) for Pakistan have been obtained from International Financial Statistics (IFS, 2007), State Bank of Pakistan, Statistical Year Book and Economic Survey of Pakistan, various issues. Economic model has been specified by the standard literature following King and Levine (1993), Ross and Levine (1997), Levine and Zervos (1998), Levine et al. (2000) and Wachtel (2001) as below.

$$
L P R I N V=\alpha_{1}+\alpha_{2} L R R I D+\alpha_{3} L B C P+\alpha_{4} L P B I N V+\alpha_{5} L P S+\alpha_{6} L B D+\mu_{t}
$$

Where, $L P R I N V=\log$ of Private fixed investment (Rs. Millions), $L R R I D=$ Real interest rate on bank deposits (Nominal interest rate on bank deposits- inflation rate) $(\%), L B C P=\log$ of Bank Credit to the private sector (Rs. Millions), $L P B I N V=$ Log of Public sector fixed investment (Rs. Millions), LPS = Log of Private savings, $L B D=$ A financial liberalization dummy variable (taking value one for the years of liberalization (1990 to onward) and zero for other years), and $\mu=$ Error term.

To examine the long run and short run relationship among the running variables, one would need to use an appropriate Co-integration technique for empirical analysis. Most of the studies have used the Johansen-Juselius (1992) and Engle Granger (1987) Co-integration technique. Johansen-Juselius technique requires that all the series should have the same order of integration.

While applying any co-integration technique, the first step is to detect the order of integration of each variable in the model which apparently rests on unit root test. To outwit this obscurity and pre-testing of unit roots, Pesaran and Shin (1995), Pesaran and Pesaran (1997) and Pesaran et al. (2001) delineated a fairly new co-integration technique i.e. Autoregressive Distributed Lag (ARDL) approach. Contrary to other single equation co-integration procedures, this technique has certain econometric advantages. At the outset, as the Engle-Granger method experiences endogeneity problems and failure to test hypothesis on the estimated coefficients in the long run, Autoregressive Distributed Lag (ARDL) approach avoids such problems. Secondly, short run and the long run parameters of the model are estimated simultaneously. Thirdly, each and every variable is presupposed as endogenous. Fourthly, the econometric methodology does not face the dilemma of finding the order of integration among the variables and of pre-testing for unit roots. Hence Autoregressive Distributed Lag (ARDL) approach of Pesaran et al. is applicable even if the underlying variables are I(0), or I(1), or mutually co-integrated, as all other methods entail that the variables in a time series regression equation are integrated of the same order, essentially one, i.e. the variables are I(1). The statistic underlying this procedure is the familiar Wald or F-statistic in a generalized Dickey-Fuller type regression, which is used to test the significance of lagged levels of the variables under consideration in a conditional unrestricted equilibrium error correction model (ECM) (Pesaran, et al., 2001). One more reason to use the ARDL approach than other co-integration techniques is its extra robustness and better performance for a small sample size as in this study. Two critical values are given by Pesaran, et al. (1997) for the co-integration test. The lower critical bound assumes that all the variables are $\mathrm{I}(0)$, while the upper bound assumes that all the variables are $\mathrm{I}(1)$.

The ARDL approach involves estimating the conditional error correction version of the ARDL model for variables under estimation. The Augmented ARDL (p, q1, q2, .. qk) is given by the following equation (Pesaran and Pesaran, 1997; Pesaran and Shin, 2001):

$$
\Delta y_{t}=\beta_{0}+\beta_{1} t+\beta_{2} y_{t-1}+\beta_{3} x_{t-1}+\sum_{i=1}^{k} \beta_{4 i} \Delta y_{t-i}+\sum_{i=0}^{k} \beta_{5 i} \Delta x_{t-i}+\varepsilon_{t}
$$

The private investment equation is specified in the form of ARDL (Autoregressive Distributed Lag) model in such a general form.

$$
\begin{aligned}
& \Delta L P R I N V=\alpha_{0}+\sum_{i=1}^{m} \gamma_{i} \square L P R I N V_{t-i}+\sum_{i=1}^{m} \xi_{i} \square R R I D_{t-i}+\sum_{i=1}^{m} \sigma_{i} \square L B C P_{t-i} \\
& +\sum_{i=1}^{m} \gamma_{i} \square L P B I N V_{t-i}+\sum_{i=1}^{m} \delta_{i} \Delta L P S_{t-i}+\lambda_{1} L P R I N V_{t-1}+\lambda_{2} R^{2} I D_{t-1} \\
& +\lambda_{3} L B C P_{t-1}+\lambda_{4} L P B I N V_{t-1}+\lambda_{5} L P S_{t-1}+\beta_{0} L B D+\zeta E C_{t-1}
\end{aligned}
$$


In the above equation, the terms with $\lambda$ s represent the long run relationship while the terms with the summation signs represent the short run dynamics and $\mathrm{EC}_{\mathrm{t}-1}$ is the error correction term.

At start, the null hypothesis of no Co-integration against the alternative hypothesis for existence of a long run relationship is tested by using F-test such as;

$\mathrm{H}_{0}: \lambda_{1}=\lambda_{2}=\ldots \ldots . \lambda \mathrm{n}=0$

$\mathrm{H}_{1}: \lambda_{1}=\lambda_{1}=\ldots . . \lambda \mathrm{n} \neq 0$

If the computed F-statistics falls above the upper bound critical value of F-tabulated developed by Pesaran, then the null of no co-integration can be rejected which implies that long run relationship exists. If the computed F-statistics falls below the lower bound, then the null of no co-integration can not be rejected. Finally, if it lies between the two bounds, the result seems inconclusive.

Once co-integration is tested and confirmed, then in the second stage, the lag order of the variables is selected by using Akaike Information Criterion or Schwarz Bayesian Criterion or by Hannan-Quin Criterion or by $\mathrm{R}^{2}$. After determining the lag order, long run and short run co-efficients of the model are estimated.

\section{Empirical Results}

In order to scrutinize the integrating level of variables, standard tests like DF-GLS, and Ng-Perron are employed. Mostly in the literature to find out the order of integration ADF (Dicky \& Fuller, 1979) and PP (Philip \& Perron, 1988 ) tests have been used extensively. Due to their poor size and power properties, both tests are not reliable for small sample data set (Dejong et al, 1992 and Harris, 2003). These tests seem to over-reject the null hypotheses when it is true and accept it when it is false. While newly proposed tests such as Dicky-Fuller generalized least square (DF-GLS) de-trending test developed by Elliot et al. (1996) and Ng-Perron test following Ng-Perron (2001) seem to solve this arising problem.

On the assumption that there is need to test the order of integration of variable $\mathrm{X}_{\mathrm{t}}$, Elliot et al. (1996), enhance the power of ADF test by de-trending procedure and DF-GLS test is based on null hypothesis $H_{0}: \delta_{0}^{*}=0$ in the regression:

$$
\Delta X_{t}^{d}=\delta^{*} X_{t-1}^{d}+\delta_{1}^{*} \Delta X_{t-1}^{d}+\ldots \ldots . .+\delta_{p-1}^{*} \Delta X_{t-p+1}^{d}+\eta_{t}
$$

where $X_{t}^{d}$ is the de-trended series and null hypotheses of this test is that $X_{t}$ has a random walk trend, possibly with drift as follows.

$$
X_{t}^{d}=X_{t}-\hat{\varphi}_{0}-\hat{\varphi}_{1} t
$$

Basically, two hypotheses are proposed, (i) $X_{t}$ is stationary about a linear time trend and (ii) it is stationary with a non-zero mean, but with no linear time trend. Considering the alternative hypotheses, the DF-GLS test is performed by first estimating the intercept and trend utilizing the generalized least square technique.

Recently, Ng-Perron (2001) has developed four test statistics utilizing GLS de-trended data $D_{t}^{d}$. The calculated values of these tests are based on forms of Philip-Perron (1988) $Z_{a}$ and $Z_{t}$ statistics, the Bhargava (1986) $R_{1}$ statistics, and The Elliot, Rotherberg and Stock (1996) created optimal best statistics. The terms are defined as follows:

$$
k=\sum_{t=2}^{T}\left(D_{t-1}^{d}\right)^{2} / T^{2}
$$

While de-trended GLS tailored statistics are as below:

$$
\begin{aligned}
& M Z_{a}^{d}=\left(T^{-1}\left(D_{T}^{d}\right)^{2}-f_{\circ}\right) /(2 k), M Z_{t}^{d}=M Z_{a} \times M S B, M S B^{d}=\left(k / f_{\circ}\right)^{1 / 2}, \\
& M P_{T}^{d}=\left\{\left(c^{k-2} c^{-1}\left(D_{T}^{d}\right)^{2} / f_{\circ}, \text { and },\left(c^{k+(1-c)}\right) T^{-1}\left(D_{T}^{d}\right)^{2} / f_{\circ}\right.\right.
\end{aligned}
$$

If $x_{t}=(1)$ in the first case, then $x_{t}=(1, t)$ will be in second case (Note 1$)$. 
The results of DF-GLS and Ng-Perron Unit Root tests for checking the stationarity of the data are shown in following table.

\section{Insert Table 1 here.}

The results of DF-GLS and Ng-Perron tests show that all the series are non-stationary at level but become stationary after taking their first difference .i.e. I(1).

First of all, at different lags on the first difference of each variable, F-Statistics is computed for the joint significance of variables with $\lambda$ s signs in the above equation. When 1 lag is imposed, there is a strong evidence of existence of co-integration among the variables the F-Calculated is 3.79, which is greater than the critical value of the F-Statistics of the upper level of the bound (3.646) at the 5 percent significance level. It is concluded from $\mathrm{F}$-statistics that there exists long run relationship among the variables.

Given the existence of long run relationship among the variables, ARDL model is estimated to see the long run and short run dynamics of the variables in equation (3).The long run and short run results are reported in table 2 and table 3 respectively.

\section{Insert Table 2 here.}

The long run results of private investment show that Bank credit to the private sector, Public investment and Private savings determine the Private investment. The coefficient of LBCP (Bank credit to the private sector) is (.483) positive and highly significant suggesting that a 1 percent change in Bank credit to the private sector leads to .48 percent increase in the level of Private investment. This means that supply of bank credit to the private sector leads to enhance the private investment. The coefficients of LPBINV and LPS are also with positive signs $(.384) \&(2.05)$ and statistically significant which suggest that public investment and private savings accelerate the private investment and play a complementary role in boosting the private investment. The coefficient of real rate of deposits, though positive and statistically significant, but its value is very small. Nevertheless its positive sign proves the McKinnon complementary hypothesis that high real deposit rate of interest promotes the capital formation (investment) by increasing the supply of credit through savings (McKinnon and Shaw, 1973). This result is also consistent with Athukorala (1998), Shrestha (2007) and Khan (1992).

\section{Insert Table 3 here.}

The results of error correction model given in Table 3 demonstrate that the lagged error correction term Ecmt-1 is negative and highly significant .Its coefficient -.85 shows a rapid adjustment process and dictates that the disequilibria of the previous period shocks is adjusted in to long run equilibrium in the current period. While results of the short run show that the change in the LBCP (Bank credit to the private sector) has very small impact on change in private investment in the short run. The short run impact of change in public investment on change in private investment is also negative which shows that public investment crowds out the private investment in short run. The change in real rate of interest on deposits (RRID) has also negative impact on change in the private investment. Private savings positively affect the change in private investment in short run.

According to Pesaran and Shin (1999), the stability of the estimated coefficient of the error correction model should also be graphically investigated. A graphical representation of CUSUM and CUSUMsq is shown in Figures 1 and 2.

The plots of CUSUM and CUSUMSQ statistics well exist within the critical bounds, implying that all coefficients of short run model (ECM) are stable.

\section{Conclusion and Recommendations}

The results of this study show that Private Savings affect the Bank Credit to the Private sector positively in the long run, which enhances the capital accumulation. The real rate of interest on deposits also positively affects the private investment in the long run. The results strongly favor the McKinnon Shaw hypothesis. The effect of financial liberalization has no positive effect on Private credit and Private investment because there is more need of deregulation of interest rate. This rate has been negative for some years due to high inflationary situation in Pakistan. Results of the study demonstrate more need for financial liberalization so that Savings could be mobilized to promote capital formation.

Based on findings of the study, it is suggested that:

- $\quad$ There should be political stability in the economy so that the structure of financial system can flourish in well manners. 
- The role of financial institutions and financial intermediaries in enhancing the credit to the private sector should be increased.

- State bank of Pakistan's capacity in controlling and guiding the activities of financial institutions and financial intermediaries be strengthened.

- $\quad$ Positive and uniformly high real rates of interest should be kept within comparable categories of Bank deposits and loans by eliminating undue reserve requirements, interest ceilings, and credit allocations.

\section{References}

Abdurohman. (2003). The role of financial development in promoting economic growth: empirical evidence of Indonesian economy. Jurnal Keuangan dan Moneter, Vol, 6 No, 2, 2003.

Agarwal, S. (2004). Real Interest Rate: Its level and Dynamics Evidence from Selected Emerging Economies. Institute of Economic Growth, Development Planning Centre, 2004.

Aggarwal, R., Jeon, B, P., and Zhao, X. (2006). Bank Exposure to Interest Rate Risks during Financial Liberalization: Evidence from South Korea. Asia Pacific Financial Markets, Vol.12, 61-90, 2006.

Agrawal, P. (2001). Interest Rates and Investment in East Asia: An Empirical Evaluation of Various Financial Liberalization Hypotheses. Journal of Economic Literature Classification, O110, O160.

Arestis, P., and Demetriades, P. (1997). Financial Development and Economic Growth: Assessing the Evidence. The Economic Journal, Vol.107,783- 799,1997.

Athukorala, P., and Rajapatirana, S. (1993). Liberalization of the Domestic Financial Market: Theoretical Issues with Evidence from Sri Lanka. International Economic Journal, Vol, 7:4, 17- 33, 1993.

Athukorala, P.C. (1998). Interest Rates, Saving and Investment: Evidence from India. Journal of Oxford Development Studies, Vol. 26, No. 2.

Ayadi, O, F., Adegbite, E, O., and Ayadi, F, S. (2008). Structural Adjustment, Financial Sector Development and Economic Prosperity in Nigeria. International Research Journal of Finance and Economics, Issue, 15, 2008.

Balassa, B. (1989). Financial Liberalization in Developing Countries, Policy, Planning and Research working papers. The World Bank, 1989.

Correa, R., and Tripati, D, R. (2004). Saving, Lending and Interest Rates: A Critique (of the Model) of Financial Liberalization in India. International Review of Applied Economics, vol.18, No.3, 289-299.

Erden, L. (2005). Structural Adjustment and Domestic Private Saving and Investment Interaction in Turkey: A Co integration Analysis. yonetim ve Ekonomi, 12/1, 95-105.

Fry, M. (1998). Saving, Investment, Growth and Financial Distortions in Pacific Asia and Other Developing Areas. International Economic Journal, Vol, 12.

Ghali, H, K. (1999). Financial Development and Economic Growth: The Tunisian Experience. Review of Development Economics, Vol, 3, 310-322, 1999.

Ghatak, S. (1997). Financial liberalization: The case of Sri Lanka. The Empirical Economics, Vol, 22,117-129.

Guryay, E., Safakli, O, V., and Tüzel, B. (2007). Financial Development and Economic Growth: Evidence from Northern Cyprus. International Research Journal of Finance and Economics, 2007.

Hachicha, N. (2005). Banking Sector Controls and Financial Deepening: A Structural Error Correction Model for Tunisia. The Developing Economies, Vol XLIII-2,265-284, 2005.

Hanif, M, N. (2003). Restructuring of Financial Sector in Pakistan. The Journal of the Institute of Bankers in Pakistan.

Hsin-Hu, C. (2002). The Direct Effect of Banking System Reforms in Taiwan. George Washington University, Department of Economics, 2002.

Iqbal, Z. (1993). Institutional Variations in Saving Behavior in Pakistan,_The Pakistan Development Review, Vol 32:4, 1293-1311.

Jankee, K. (2003). Interest Rate Determination in the Post-Liberalization Period in Mauritius, Law, Management and Social Sciences Research Journal, Vol, 5, 2003.

Khan A, H., Hasan, L., and Malik, A. (1992). Dependency Ratio, Foreign Capital Inflows and the Rate of Savings in Pakistan. The Pakistan Development Review, Vol 31:4.843-856, 1992. 
Khan, M, A., and A, Qayyum. (2006). Trade Liberalization, Financial Sector Reforms and Growth: The Pakistan Development Review, Vol 45: 4, 711- 731.

King, R, G., and Levine, R. (1993). Finance and Growth: Schumpeter Might be Right, The Quarterly_Journal of Economics, Vol.108, No. 3, 717-737.

Mckinnon, R, I. (1973). Money and Capital in Economic Development, Washington, DC, Brooking Institute.Pesaran, H, M. and Pesaran, B. (1997). Working with microfit 4.0: Interactive Econometric Analysis, Oxford university press.

Roubini, N., and Sala-i-Martin, X. (1992). Financial Repression and Economic Growth. Journal of Development Economics, Vol, 39, 5-30, 1992.

Shrestha, M., and Chowdhury, K. (2007). Testing Financial Liberalization Hypothesis with ARDL Modeling Approach. The Applied Financial Economics, Vol 17, 1529-1540.

Thirlwall, A, P. (2004). The Mobilisation of savings for growth and Development in developing countries, Monetaria e Investigacion Economica.

Zaidi, E. (2008). SBP hikes interest rate by 2 per cent, [Online] Available: www.nation.com.pk ,2008.

Note

Note $1 . \bar{\alpha}=-7$, If $x_{t}=\{1\}$ and $\bar{c}=-13.7 \quad \bar{\alpha}=-7$, If $x_{t}=\{1, t\}$

Table 1. DF-GLS \& Ng-Perron Unit Root Test

\begin{tabular}{|c|c|c|c|c|}
\hline Variables & \multicolumn{2}{|c|}{ DF-GLS at level } & \multicolumn{2}{|c|}{ DF-GLS at $1^{\text {st }}$ difference } \\
\hline LPRINV & \multicolumn{2}{|c|}{-2.3152} & \multicolumn{2}{|c|}{$-5.9787^{*}$} \\
\hline RRID & \multicolumn{2}{|c|}{-2.9262} & \multicolumn{2}{|c|}{$-5.4915^{*}$} \\
\hline LBCP & \multicolumn{2}{|c|}{-2.9418} & \multicolumn{2}{|c|}{$-4.3743^{*}$} \\
\hline LPBINV & \multicolumn{2}{|c|}{-2.1722} & \multicolumn{2}{|c|}{$-4.1514 *$} \\
\hline LPS & \multicolumn{2}{|c|}{-2.8872} & \multicolumn{2}{|c|}{$-5.5842 *$} \\
\hline \multicolumn{5}{|c|}{ Ng-Perron at level } \\
\hline variables & MZa & MZt & MSB & MPT \\
\hline LPRINV & -8.328 & -1.999 & 0.240 & 11.070 \\
\hline RRID & -11.024 & -2.323 & 0.211 & 8.390 \\
\hline LBCP & -9.878 & -2.216 & 0.224 & 9.252 \\
\hline LPBINV & -3.737 & -1.367 & 0.368 & 24.385 \\
\hline LPS & -9.378 & -2.160 & 0.230 & 9.738 \\
\hline \multicolumn{5}{|c|}{ Ng-Perron at $1^{\text {st }}$ difference } \\
\hline LPRINV & $-13.177^{*}$ & -2.550 & 0.194 & 7.008 \\
\hline RRID & $-16.729 *$ & -2.891 & 0.173 & 5.454 \\
\hline LBCP & $-12.207 *$ & -2.469 & 0.202 & 7.472 \\
\hline LPBINV & $-13.631 *$ & -2.472 & 0.181 & 7.451 \\
\hline LPS & $-13.829 *$ & -2.628 & 0.190 & 6.597 \\
\hline
\end{tabular}

Note: *Ng-Perron (2001, Table 1) \&*Elliott- Rothenberg- Stock (1996, Table 1)

Table 2. ARDL $(1,1,0,1,0)$ Long Run Results

\begin{tabular}{|l|l|l|l|}
\hline \multicolumn{5}{|c|}{ Dependent Variable LPRINV } \\
\hline Regressor & Coefficient & S.E. & T-Ratio \\
\hline RRID & $.005 * *$ & .002 & 2.021 \\
\hline LBCP & $.482 * * *$ & .029 & 16.288 \\
\hline LPBINV & $.383 * * *$ & .142 & 2.697 \\
\hline LPS & $2.049 * * *$ & .615 & 3.333 \\
\hline LBD & -.020 & .039 & -.521 \\
\hline INPT & -.510 & .466 & -1.093 \\
\hline
\end{tabular}

$* * *$ shows the coefficient is significantly different from zero at $(0.01 \mathrm{p})$ level.

** shows the coefficient is significantly different from zero at $(0.05 \mathrm{p})$ level. 
Table 3. ARDL (1, 1, 0, 1, 0) Error Correction Mechanism (Short run Dynamics)

\begin{tabular}{|l|l|l|l|}
\hline \multicolumn{4}{|c|}{ Dependent Variable DLPRINV } \\
\hline Regressor & Coefficient & Standard Error & T-Ratio \\
\hline dPRINV & .281 & .190 & 1.475 \\
\hline dRRID & $-.004 * *$ & .002 & -2.078 \\
\hline dLBCP & $.409 * * *$ & .100 & 4.093 \\
\hline dLPBINV & -.057 & .165 & -.352 \\
\hline dLPS & $.833 * * *$ & .126 & -2.647 \\
\hline dLBD & -.017 & .032 & -.538 \\
\hline dINPT & -.432 & .422 & -1.025 \\
\hline Ecm(-1) & $-.848 * * *$ & .211 & -4.004 \\
\hline R-Square & .58 & F-Stats & 3.616 \\
\hline Adj. R-Square & .38 & Log. L & 64.15 \\
\hline AIC & 53.15 & SBC & 48.08 \\
\hline Durbin Watson & 45.08 & & \\
\hline
\end{tabular}

*** showed that coefficient is significantly different from zero at $(0.01 \mathrm{p})$ level.

** showed that coefficient is significantly different from zero at $(0.05 \mathrm{p})$ level.

Plot of Cumulative Sum of Recursive Residuals

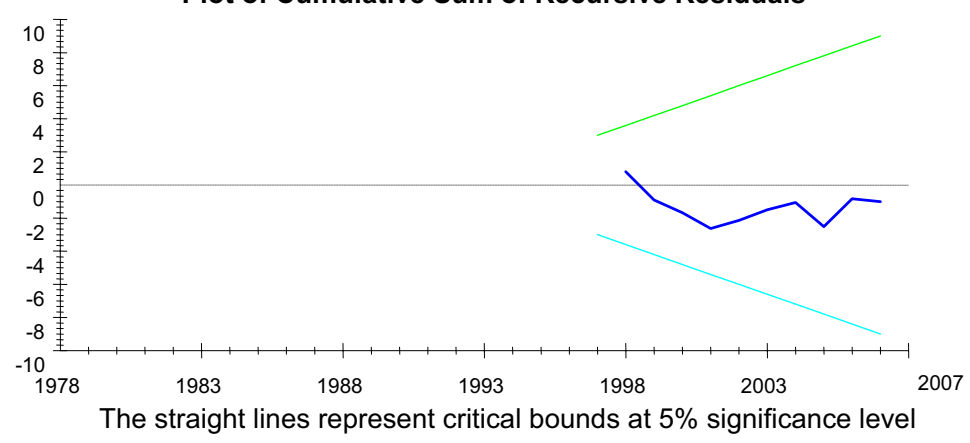

Fig 1. Plot of CUSUM of Private Investment Function

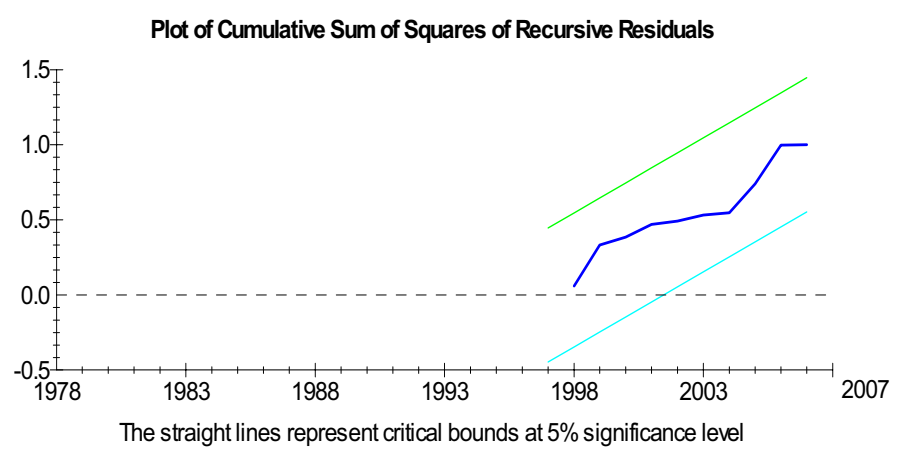

Fig 2. Plot of CUSUMSQ of Private Investment Function 